\title{
International Advisory Boards in the World
}

\author{
Adnan Zahed
}

\section{Introduction}

Many scientific institutions and major industrial organizations, in their keenness to benefit from the experience of internationally prestigious advisory and consultative bodies, draw up long and short-term plans for their formation. These advisory and consultative bodies comprise of elite and authoritative groups of scientific, industrial, and administrative experts. The assistance of such bodies is sought to support educational institutions' efforts to achieve quality enhancements and improvements of such credibility as to be worthy of international recognition [1-3]. Advisory boards are not, and are not intended to be, substitutes for statutory boards of directors, which are responsible for internal operational planning and implementation within the concerned institutions. Indeed, if properly constituted, advisory boards are intended to complement and strengthen existing executive boards, by offering advice and guidance to aid them in the successful performance of their tasks. Advisory boards' targets and the criteria for board members' selection have to be clearly enunciated from the very beginning, in order for maximum benefit to be obtained from such boards by concerned institutions.

The motive for following this strategy could be to ensure that concerned educational institutions receive expert advice on new high technology and scientific advances, or to enable them to gain insight into conducting business in diverse global markets. This chapter provides an overview of International Advisory Boards (IABs), consulted by a sample of universities and major organizations in the world. We have outlined the definition, objectives, composition, and meeting schedules of the IABs in such institutions and organizations.

The following section covers the definition, objectives, and function of the International Advisory Board at King Abdulaziz University. It also provides examples of other distinguished universities and organizations globally, that have established international advisory bodies.

\footnotetext{
A. Zahed $(\square)$

King Abdulaziz University, Jeddah, Saudi Arabia e-mail: azahed@kau.edu.sa 


\section{International Advisory Board Definition}

IABs, or International Advisory Councils (IACs), are "international consultative bodies purposely created with the intention that the experience, deliberations and ideas of their members are able to be utilized, so as to make substantive contributions to various fields of development" [4]. IABs and IACs do not have decisionmaking powers, but attempt to inform higher administrative teams or university councils on strategic matters and imperatives, and provide expert consultative mechanisms.

\section{Who Should Serve on an International Advisory Board or International Advisory Council?}

For brevity's sake in the present context, the terms 'board' or 'advisory board' are subsequently used predominately and refer to either IABs or IACs.

The composition of an advisory board should be based on an organization's goals and priorities. Hence, a board intended to provide an institution with advice on higher educational planning is likely to differ significantly from one formed in order to offer insight into the latest medical or engineering research [1].

Any such advisory board membership composition is entirely dependent on its intended role and on its aims being affirmed with absolute clarity. Is it intended to be a business development tool aiming to raise an institute's or organization's profile and initiate appropriate commercial introductions, or is the intention to increase the main executive board's knowledge base and understanding of specialist issues? Overall, the board's objective will determine its composition [1], and a judicious combination of experience and knowledge can help enhance its performance. Therefore, most advisory board members have experience gained from a wide range of higher educational institutions, research bodies, commercial and industrial sectors, and functional disciplines.

\section{IAB/IAC Functions}

The main functions of IABs/IACs include [2-4]:

- Providing independent external advice, through board meetings and engagement with projects and new initiatives.

- Assisting in developing corporate and institutional relationships at the national and international level.

- Assisting in building and delivering cases for institutional change as and when perceived and required. 
- Helping to increase contributions of practitioners into research, learning, and teaching, including creating and maintaining direct contact with institutions' academic staff and students.

- Transferring world-class international universities' and companies' accumulated expertise to the concerned local organizations in matters of education, research, technology transfer, international cooperation, marketing, and other relevant issues.

- Enhancing the level of international cooperation between concerned local universities and distinguished world-class universities.

- Advising on the overall strategy and direction of institutions, particularly in terms of research and education, and on improving their external profiles, and advising on appropriate responses to other related issues, as and when they arise.

- Providing informed viewpoints in the evaluation concerning the educational aspects of entrepreneurial programs, and on effective collaboration with the business sector.

- Assisting and guiding universities to achieve their visions of academic excellence and service to community.

\section{Examples of International Advisory Boards/Councils}

As previously mentioned, many institutions and companies decide to create advisory boards when it is apparent that there is a subject area where experts can positively reinforce the knowledge, understanding, and strategic thinking of boards and management teams. Experienced advisory board members can provide specialist advice and extend the range of skills and understanding of management teams in areas outside of their day-to-day fields of expertise. In the following section are some examples of universities and associations that have established advisory boards to positively impact their efforts toward the achievement of their missions and goals.

The following section is intended to provide an in-depth understanding of King Abdulaziz University's International Advisory Board (IAB), its objectives, and the criteria applied in its membership selection. It also enumerates the last seven meetings' topics and themes [2, 5-12].

\section{International Advisory Board of King Abdulaziz University (KAU), Saudi Arabia}

\subsection{Introduction}

King Abdulaziz University (KAU) is a distinguished educational institution in the Middle East that has undertaken substantial transformational steps to establish partnerships and cooperative programs with national and international educational and industrial institutions in order to enhance and improve its academic 
and educational profile and status. In pursuit of achieving a substantive leap forward of quality in levels of performance in education, academic research, and community services, KAU created an IAB in 2010. It was constituted to enable $\mathrm{KAU}$ to benefit from the experience of internationally acclaimed intellectual pioneers in industry and higher education who have made significant contributions to the development of higher education world-wide. The KAU President, Osama Tayeb, states, "This board will represent a major driving force that will guide KAU towards consolidating the cohesion and consistency of all its subsystems for optimum performance" [6].

The aim of the advisory board is to ensure the university leadership's ready access to diverse input and ideas from the international academic and business communities during scheduled consultations. It is intended that this input, advice, and guidance will assist and support KAU in its quest for academic and educational excellence and international recognition.

To ensure that we receive a diversity of perspectives of ideas and views, the advisory board represents, not only a variety of disciplines, but also an extensive range of cultural backgrounds. KAU's IAB meetings are held in diverse countries in order to further underscore the goal of achieving a truly global view and spirit.

\subsection{IAB Objectives}

- To participate in reformulating KAU's strategic objectives, priorities, procedures, and performance tracks in order to facilitate the achievement of its goals in the educational process, scientific research, and community service.

- To capitalize on the board members' knowledge, intellect, experience, and authority in supporting KAU's fields, opportunities, and domains to enable the university to excel and attain distinction in achievements in knowledge, science, and technology.

- To enhance the university's status and international profile through its achievements, especially, in the fields of research and innovation.

- To contribute to the formation of strategic alliances between the university and service sectors, productive establishments in the local community, and international industrial companies and scientific knowledge institutions.

- To establish and activate partnerships with international universities and research centers.

- To deliver consultation and advice with respect to the topics studied by the board.

- To provide technical, academic, and administrative consultancy to KAU as well as to other national institutions wishing to take advantage of the expertise, experience, and qualifications of the board's members. 


\subsection{IAB Members}

KAU has carefully selected the IAB members to include an array of eminent authoritative figures from industry and higher education and other fields, who are renowned for their achievements and internationally recognized contributions in their respective fields.

The IAB has 18 members, initially appointed for two years, and who may be reappointed for second and third terms for up to six consecutive years of service. The initial search for suitable members lasted over two years. The IAB's first membership included presidents of international universities, namely; Ohio State University, USA; Maastricht University, The Netherlands; University of Vienna, Austria; University of Helsinki, Finland; University of Copenhagen, Denmark; Nanyang Technological University (NTU), Singapore; IE University, Spain; Bilkent University, Turkey; Fudan University, China; and Nagoya University, Japan. In addition, there were two prominent academics, namely: the Dean of Harvard School of Public Health (USA) and the Founder and Chairman of the Institute of Plant Biotechnology for Developing Countries. International professional associations were represented by the President of the European Medical Association and the Executive Director of the Council for International Exchange of Scholars. The international employment market was represented by the President and Executive Officer of Hitachi Company, Japan, and the President and Chief Executive Officer of Nissan Motor Company, Japan. The local employment market was represented by the President and Chief Executive Officer of Al-Amoudi Group and the Founder and Chief Executive Officer of Gulf One Investment Bank. The KAU President is the IAB Chairman, while the Secretary-General is the KAU VicePresident for Graduate Studies and Scientific Research [5, 8-12].

Figures 1, 2 and 3 show the IAB members during three different meetings at different venues: King Abdulaziz University in Jeddah, Vienna University, Austria, and IE University in Spain.

The IAB held its first meeting on the King Abdulaziz University premises on the 29th and 30th of January, 2011, providing an opportunity for the members to acquaint themselves with the university facilities, academic programs, and activities. This meeting was the starting point on the ambitious journey intended to take the university toward the realization of KAU's objective of earning and securing its place among the world's most distinguished international universities.

KAU provides commensurate remuneration, flight tickets, and accommodation to IAB board members for board meetings.

\subsection{IAB Meetings}

IAB meetings are held biannually. One meeting is held on KAU's home campus in Jeddah, Saudi Arabia, while the other is held at an international location on the university campus of a board member based outside the Kingdom. Each meeting 


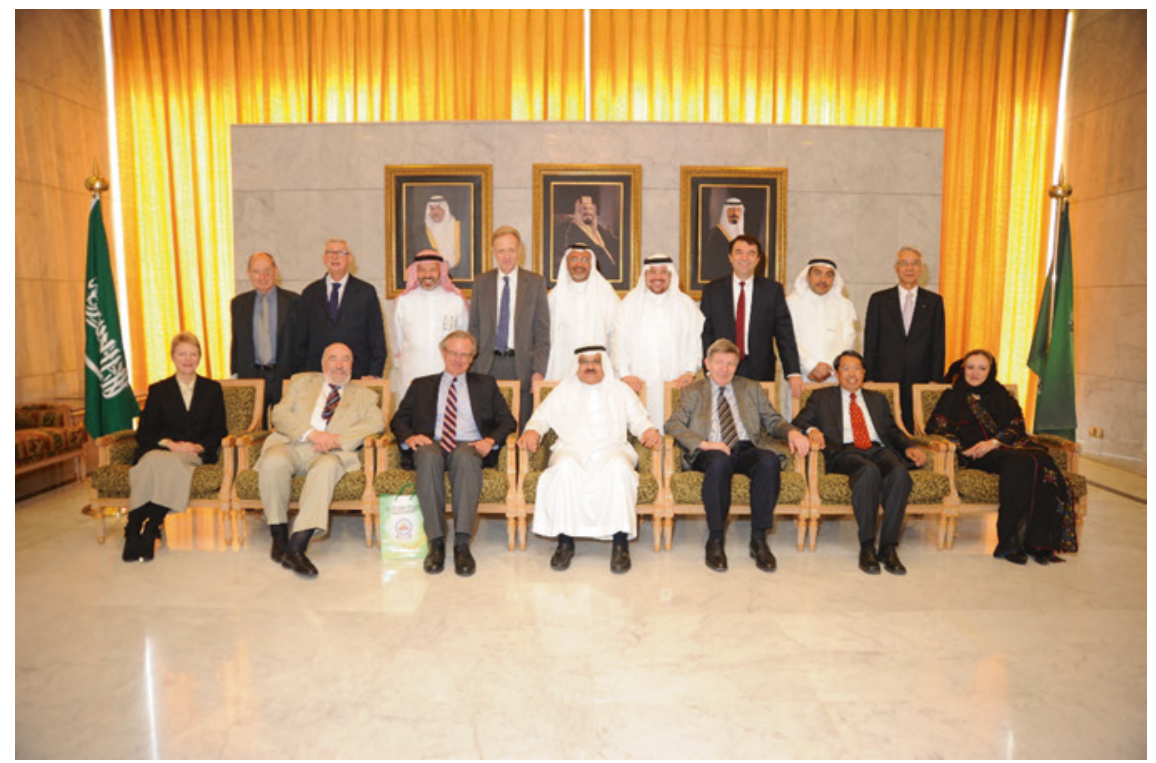

Fig. 1 IAB first meeting at King Abdulaziz University, Jeddah, KSA

Fig. 2 IAB second meeting at Vienna University, Austria

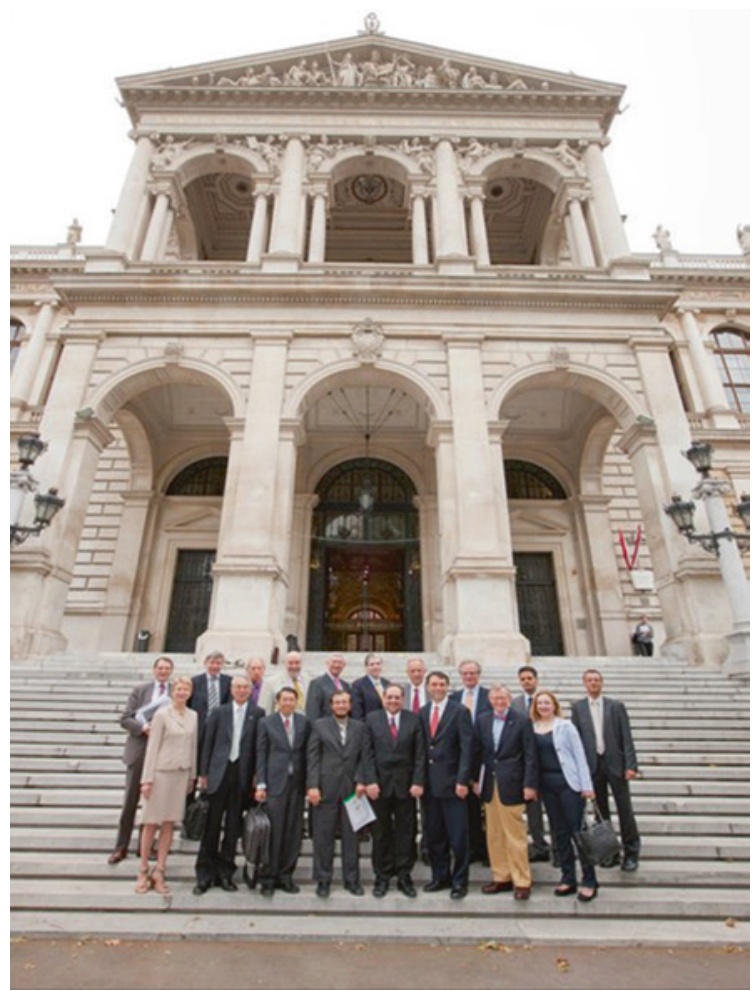




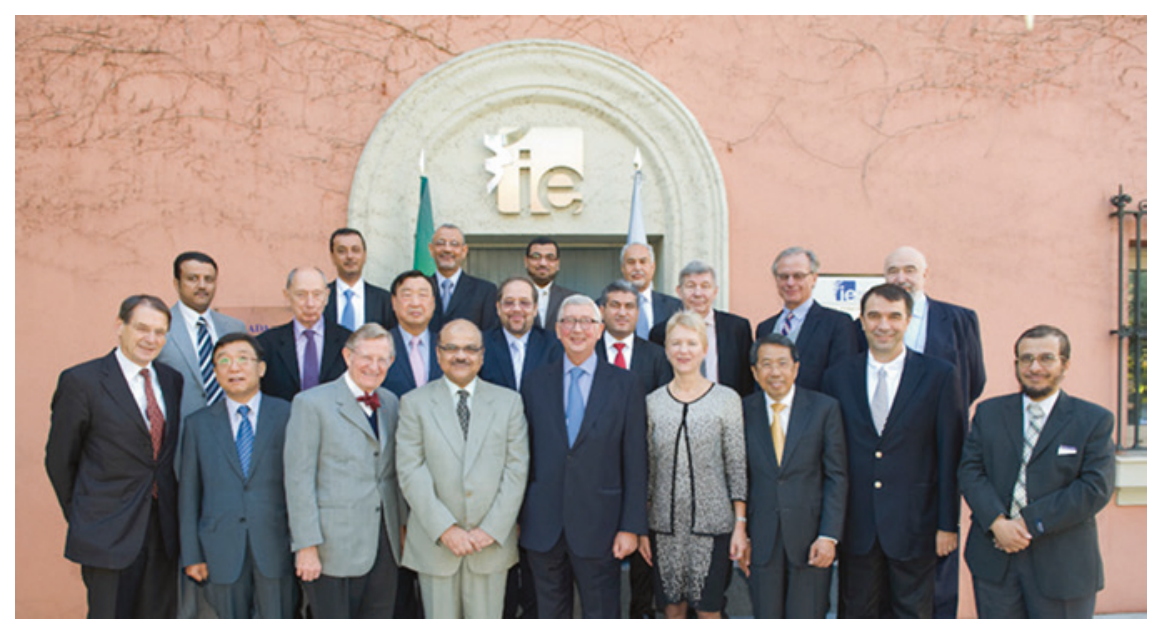

Fig. 3 IAB fourth meeting at IE University, Spain

has a maximum duration of three days. Figure $4 \mathrm{a}-\mathrm{c}$ show the IAB members during meeting sessions.

The principal point of contact between the university and the IAB members is via the Vice-President for Graduate Studies and Research, who acts as Board Secretary General. In most meetings, all KAU Vice-Presidents and selected KAU faculty members (non-permanent board members) are invited to attend and participate, so as to ensure the creation and maintenance of close links between the IAB members and the management team responsible for the operational oversight and day-to-day running of the university. The selection of non-permanent board members for invitation depends on the specialization and main theme of the meeting's discussion and deliberations.

Since the establishment of the KAU IAB, seven meetings have been held to date as detailed in the following table, while the agenda of the sixth meeting is presented in the Appendix:

\begin{tabular}{|c|c|c|c|}
\hline Meeting & Place & Date & The main subject of the meeting \\
\hline First & KAU, Jeddah, K.S.A. & $\begin{array}{l}25-26 / 2 / 1432 \mathrm{H} \\
(29-30 / 1 / 2011 \mathrm{G})\end{array}$ & $\begin{array}{l}\text { Introduction of KAU and its strategic plan } \\
\text { to the IAB members }\end{array}$ \\
\hline Second & $\begin{array}{l}\text { Vienna University, } \\
\text { Austria }\end{array}$ & $\begin{array}{l}1-2 / 8 / 1432 \mathrm{H} \\
(2-3 / 7 / 2011 \mathrm{G})\end{array}$ & $\begin{array}{l}\text { Ways and means of developing scientific } \\
\text { research at KAU }\end{array}$ \\
\hline Third & KAU, Jeddah, K.S.A. & $\begin{array}{l}26-27 / 3 / 1433 \mathrm{H} \\
(18-19 / 1 / 2012 \mathrm{G})\end{array}$ & $\begin{array}{l}\text { KAU steps toward innovation and creativity } \\
\text { (Part 1) }\end{array}$ \\
\hline Fourth & IE University, Spain & $\begin{array}{l}27-28 / 11 / 1432 \mathrm{H} \\
(13-14 / 10 / 2012 \mathrm{G})\end{array}$ & $\begin{array}{l}\text { KAU steps toward innovation and creativity } \\
\text { (Part 2) }\end{array}$ \\
\hline Fifth & KAU, Jeddah, K.S.A. & $\begin{array}{l}1-2 / 7 / 1434 \mathrm{H} \\
(11-12 / 5 / 2013 \mathrm{G})\end{array}$ & $\begin{array}{l}\text { Ways and means to excel and achieve dis- } \\
\text { tinction in educating and learning (Part 1) }\end{array}$ \\
\hline Sixth & $\begin{array}{l}\text { Bilkent University, } \\
\text { Turkey }\end{array}$ & $\begin{array}{l}\text { 19-21/1/1435H } \\
(22-24 / 11 / 2013 \mathrm{G})\end{array}$ & $\begin{array}{l}\text { Ways and means to excel and achieve dis- } \\
\text { tinction in educating and learning (Part 2) }\end{array}$ \\
\hline Seventh & KAU, Jeddah, K.S.A. & $\begin{array}{l}25-26 / 11 / 1435 \mathrm{H} \\
(20-21 / 9 / 2014 \mathrm{G})\end{array}$ & KAU Third Strategic Plan for WCU \\
\hline
\end{tabular}



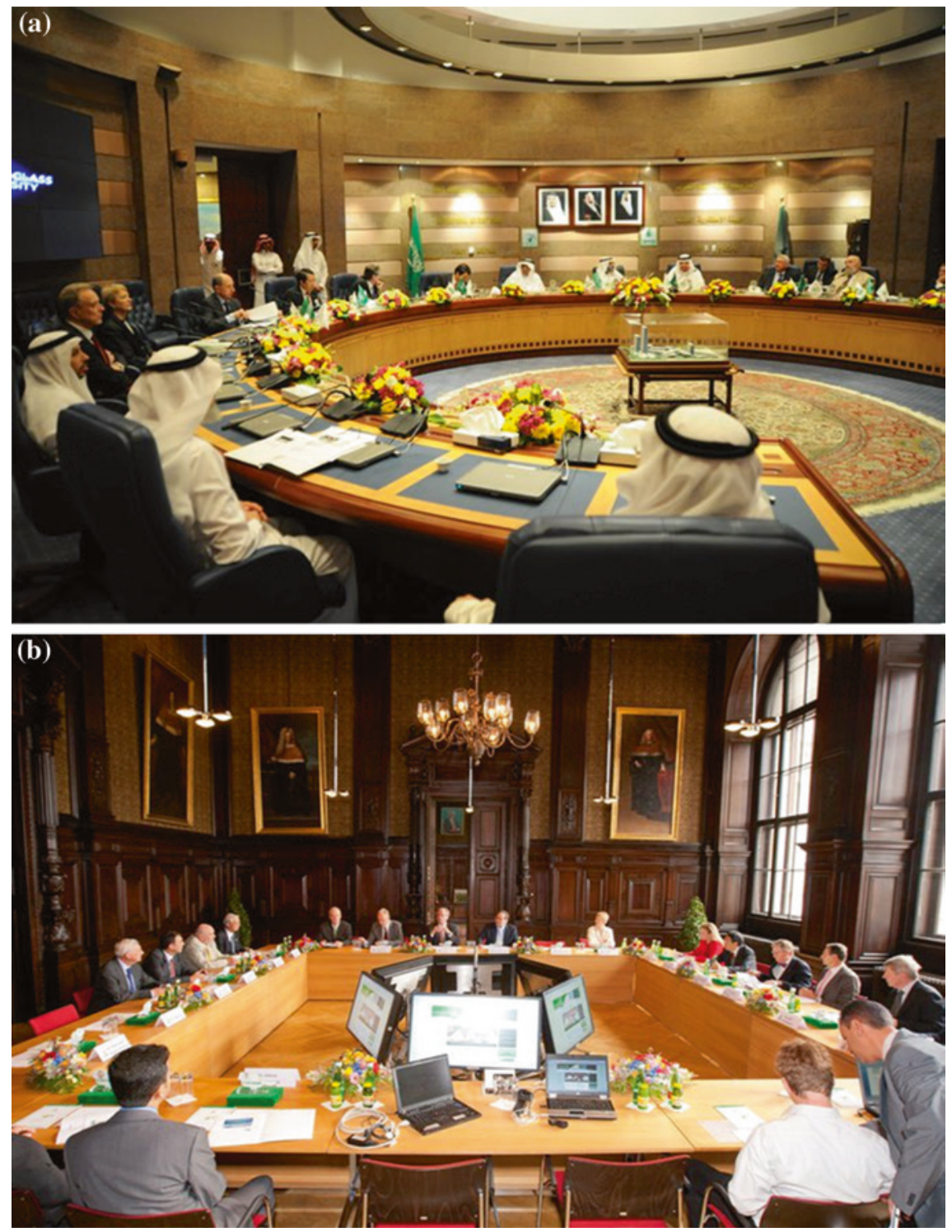

Fig. 4 a-c IAB meeting sessions in progress 


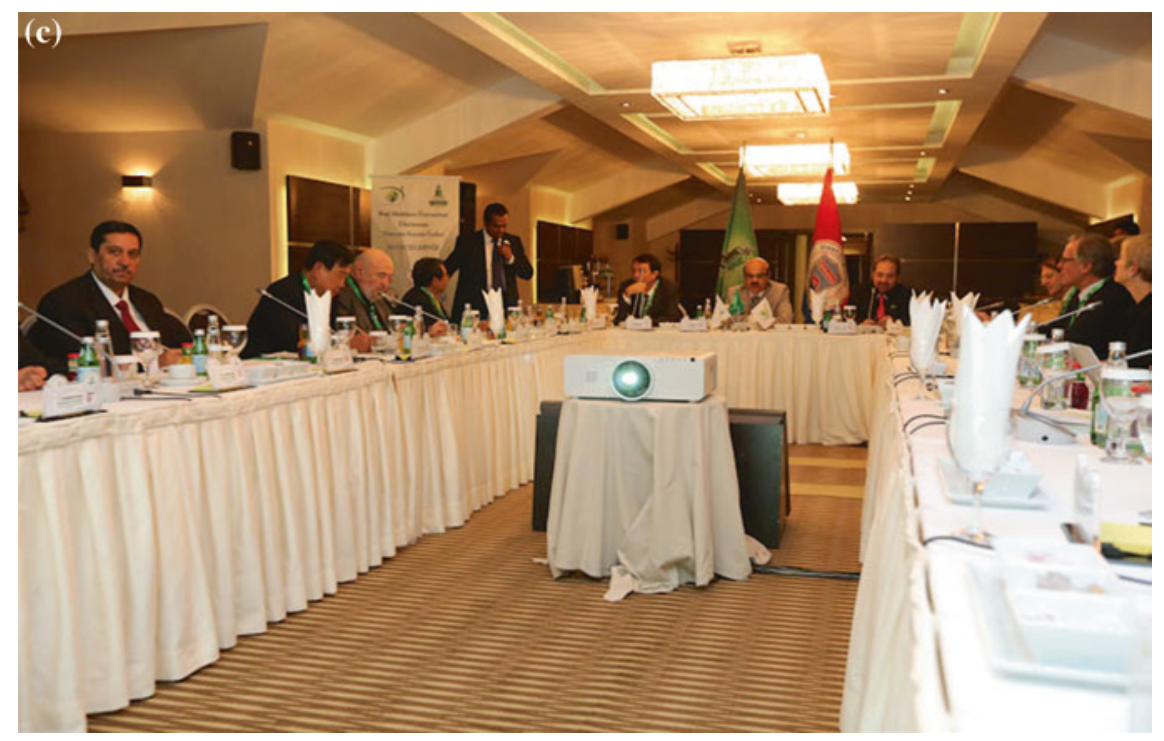

Fig. 4 (continued)

\section{Examples of International Advisory Boards and International Advisory Councils at Other Universities}

As previously mentioned, numerous universities and institutions around the world have established international advisory bodies in order to benefit from their members' expertise. Some of these universities are ranked within the top 500 world universities, while others are, as yet, unranked.

The following section contains examples of universities in the US, Europe, Asia, and Australia which have established IABs. The following list is not exhaustive.

\subsection{International Advisory Council of King Abdullah University for Science and Technology, KSA}

King Abdullah University for Science and Technology (KAUST) is an international, graduate-level research university in Saudi Arabia dedicated to inspiring a new age of scientific achievement in the Kingdom that will benefit the nation, the region, and the world. The President's IAC supports and advises the KAUST President on the overall academic development of the university. This development is intended to firmly establish KAUST as a globally renowned graduate university and a major and significant contributor to scientific and technological advances [13]. 
The IAC is an eminent body of widely respected scholars, researchers, and academic leaders, in addition to those with other areas of domain expertise deemed supportive to the president. Council members are selected on the basis of their leadership, expertise, and experience in scientific, technical, business, and academic domains.

The internationally diverse council membership reflects cultural and geographical diversity spanning Asia, Europe, and North America. The board membership is complemented by Saudi council members, who are able to advise the president on certain relationships and other issues specific to Saudi Arabia. The IAC consists of 14 members representing a number of disciplines, including:

- Professor Richard Friend (Chair), Cavendish Professor of Physics, Cavendish Laboratory, University of Cambridge, UK

- Professor Alice M. Agogino, Roscoe and Elizabeth Hughes Professor of Mechanical Engineering, University of California, Berkeley, United States

- Mr. Mohamed H. Al-Mady, Vice Chairman \& CEO, Saudi Basic Industries Corporation (SABIC), Saudi Arabia

- Dr. Mohammed ibn Ibrahim Al-Suwaiyel, President, King Abdulaziz City for Science and Technology (KACST), Saudi Arabia.

\subsection{International Advisory Board, University of Edinburgh, $U K$}

The Quacquarelli Symonds World University Rankings (QS World University Rankings) were first compiled in 2004, evaluating 700 universities in the world and ranking the top 400. University of Edinburgh has consistently been ranked within the top 20 institutions since 2004. The university ranked at 17 in the QS world rankings in 2014 [14].

The IAB was established to provide independent, external, and commercially orientated advice to the University of Edinburgh's Business School [4]. The principal points of contact between the school and the IAB are via the University Dean and the University Corporate Engagement Manager, the latter acting as IAB Secretary. Members of the executive team have a standing invitation to board meetings in order to ensure tight linkage between the school's external advisors and the team responsible for its day-to-day running.

The board contains a broad range of members of the international business community, diverse in gender and representative of both the public and private sectors [4]. It consists of 16 members representing different area specialties, including:

- Mark Astaire, Chairman, Investment Banking and Vice Chairman EMEA, ECMC, Barclays

- Simon Bray, Director of Santander Universities UK

- John D. Campbell OBE, FRSA (Chair), Senior Managing Director, State Street Global Services UK, Middle East and Africa (UKMEA) 
- Melanie A Czarra, Managing Director, Head of Primary Debt Markets, Mizuho International plc.

The board holds two or three face-to-face meetings a year and meets on an asneeded basis by teleconference. Board members are kept abreast of school events by email.

\subsection{International Advisory Council of Università Bocconi, Italy}

Università Bocconi is a private Italian university, founded in 1902. The university is an example of an unranked institution, not appearing within the top 500 world university rankings. The university has established an IAC to assist the board of directors in designing and defining the university's international strategy [15]. The council brings together business leaders, policy makers, and academics from Europe and the rest of the world. Its fundamental mission is to provide feedback on the projects proposed by the University Rector and its Chief Executive Officer, to suggest new avenues for strategic development and to guide innovative thinking on the university's future.

The IAC consists of prominent international figures, bringing their European and global perspectives and vision to Bocconi. These global corporate managers and international academics are joined by leading Italian managers who are active in the internationalization of their businesses. Three representatives of Università Bocconi are also members [15].

\subsection{International Advisory Board, University of Oxford, UK}

The University of Oxford has consistently been ranked within the top six institutions since the QS World University Rankings were started in 2004. The university ranked at five in the QS World University Rankings in 2014 [14].

The University of Oxford is the oldest university in the English-speaking world. It is one of the world's leading universities, and it occupied the fourth place in the world in the Times Higher Education (THE) World University Ranking in 2013/2014. The University of Oxford established an IAB for its Business School that draws on the talents and knowledge of renowned leaders from many parts of the world.

The board was formed to advise the school's management on its future direction. The IAB is comprised of 12 globally distinguished business scholars and leaders, including [16]:

- Mark Carney, Governor of the Bank of England

- W.J. Clinton, 42nd President of the United States 
- N.O. Lweala, Minister of Finance and Coordinating Minister of the Economy, Nigeria

- P. Arida, Managing Partner and Chairman of Asset Management, BTG Pactual.

Additional information concerning this IAB and its members can be accessed via link [16].

\subsection{International Advisory Board of Sri Ramaswamy Memorial (SRM) University, India}

SRM University's IAB is actively involved in the creation of an increasingly robust international dimension in curriculum, research, and teaching methodology, by bringing together students and faculty from renowned overseas universities.

The IAB has helped create an upbeat environment at SRM University by opening up possibilities for students and faculty, creating avenues for research, and establishing the necessary foundations for successful careers.

The IAB comprises of approximately 60 members from around the world, drawn from different specializations, including [17]:

- Dr. Al Lieberman, Professor of Marketing, Executive Director Entertainment, Media and Technology Program, Stern School of Business, NYU

- Professor Allan Baker, Associate Dean, Administration and International Projects, School of Cinematic Arts, University of Southern California

- Mr. Allan L. Fisher, Senior Vice President for Product Strategy and Development, Laureate Higher Education Group; Ex-President and CEO iCarnegie Inc., Pittsburgh

- Dr. Bob Hoekstra, Former CEO, Philips R\&D Center, The Netherlands; CEO, Opportunity India Consulting, The Netherlands.

\subsection{International Advisory Board of Texas A\&M University, USA}

Texas A\&M University has consistently been ranked within the top 200 institutions in ranking systems. It was ranked at 165 in the QS world rankings in 2014 [14].

The IAB of Texas A\&M University, consisting of approximately 40 members from business, government, education, and other areas, was created in 1992. The board advises the university on international program development and other areas of major concern. Its members participate in the university's international activities and assist in the creation of an international network for the university. The board also promotes awareness of international programs and issues [18]. 
Board members include:

- Francisco Alcalá, President of Frajal, S.C., a consulting firm specializing in the areas of corporate governance, agribusiness, education, and management.

- Alberto Alemán Zubieta, CEO of the Panama Canal Authority (ACP), the autonomous agency that manages the Panama Canal which is the leading interoceanic waterway that serves world maritime commerce.

- Klaus Aurisch, business consultant in European Union matters, German attorney, and university lecturer in international relations.

- Jorge Bermudez, President and CEO of the Byebrook Group, a small firm dedicated to research and advisory work in the financial services industry.

Additional information concerning this IAB and its members can be accessed via link [18].

\subsection{Lund University International Advisory Board, Sweden}

Lund University was ranked at 65 in the world and as the top Swedish university in the 2014 QS Ranking [14].

The IAB is made up of prominent international academics with extensive leadership experience, drawn from a variety of academic disciplines. The board's function is to monitor and assess research, education, and management at the university. It also has an advisory function with regard to strategy, development, innovation, and education and research goals [19]. The Deputy Vice-Chancellor is responsible for coordination of work between the university and the IAB.

The following are a selection of members of the 2010-2014 IAB:

- Provost Judyth Sachs, Macquarie University, Sydney, Australia

- Professor Jan-Anders Månsson, École Polytechnique Fédérale de Lausanne (EPFL), Switzerland

- Dr. John Hood, Robertson Foundation, USA.

\subsection{International Advisory Board of James Cook University, Australia}

The function of the IAB is to advise the Deputy Vice-Chancellor (Research and Innovation), the Management Committee, and the Director. Advice is sought on strategic and academic matters that are conducive to the realization of the vision of the Cairns Institute at James Cook University and to the implementation of its strategic intent. Its members are distinguished, internationally renowned individuals, recognized by their peers as having made outstanding contributions to one or more of the academic disciplines represented within the institute. The board normally 
meets at least once a year in Cairns with the Vice-Chancellor, Deputy ViceChancellor (Research and Innovation), Management Committee, Director, and academic leaders of the Cairns Institute, as part of its review and planning cycle.

The IAB is comprised of nine members appointed by the Vice-Chancellor for a period of five years and includes the following [20]:

- Professor Chris Cocklin (ex-officio), Senior Deputy Vice-Chancellor, James Cook University

- Professor Barbara Glowczewski, Director of Research, Centre National de la Recherche Scientifique, Laboratoire d'Anthropologie Sociale, Collège de France

- Professor Jon Tikivanotau M. Jonassen, Department of Political Science, College of Business, Computing and Government, Brigham Young University, Hawaii

- Professor Bruce Kapferer, Professor of Anthropology, University of Bergen, Norway.

\subsection{The International Advisory Board, University of Helsinki, Finland}

The University of Helsinki has consistently been ranked within the top hundred institutions in the various ranking systems. It was ranked 67 in the 2014 QS World Rankings [14].

The IAB is made up of nine scholars and practitioners of environmental and applied aesthetics from around the world. The board promotes research in aesthetics, international exchange, and cooperation between universities and research centers. IAB tasks also include evaluating and commenting on the International Institute of Applied Aesthetics (IIAA) project plans. Many IAB members attend events in Finland to pool and share their scholarly expertise in their specialized fields [21]. The IAB has nine members including:

- Professor Emeritus Arnold Berleant, Castine, ME, USA

- Dr. Emily Brady, University of Edinburgh, UK

- Professor Wangheng Chen, Wuhan University, China

- Professor Kenneth Olwig, SLU-Arnap, Department of Landscape Planning, Sweden.

\subsection{The International Advisory Board, King Fahd University of Petroleum and Minerals (KFUPM), KSA}

King Fahd University of Petroleum and Minerals (KFUPM), Kingdom of Saudi Arabia, was ranked at 225 in the world, in the 2014 QS World Rankings [14]. Its groundbreaking IAB was established in March 2007. The IAB is a highly prestigious panel composed of senior academic and corporate leaders [22]. The IAB 
membership was selected from world-class organizations. The board fulfills important advisory functions concerning the university's strategic planning. It also focuses on the provision of advice and guidance on the university's outreach to peer institutions for the acquisition, implementation, and utilization of innovations and developments in research and curriculum. It also guides and assists KFUPM's academic administration, and the university's provision of community service.

The IAB was established for the purpose of providing advice and guidance on important issues to the university and its community. The IAB features leading experts, currently or formerly affiliated with some of the most successful and respected companies and universities. The IAB has 14 members selected from world-class organizations, including [23]:

- Martin Jischke, President Emeritus, Purdue University, Indiana, USA

- Andrew F. Gould, Non-Executive Chairman of the Board, BG Group Plc, UK

- Robert J. Birgeneau, Chancellor, University of California, Berkeley, USA

- Olivier Appert, Chairman and Chief Executive Officer, Institut Francais du Petrole (IFP). He is also a Director of Technip, Director of Storengy and of the Institut de Physique du Globe de Paris, France.

\section{Additional Examples of International Advisory Boards and International Advisory Committees}

There are a considerable number of established organizations and consulting bodies that offer advice and help executive boards in the successful performance of their duties. They are too numerous to all have places in this chapter, but we include the three following bodies, as we deem them as being of particular significance, and as of having especially significant impact.

\subsection{International Advisory Board (IAB) of the Academic Ranking of World Universities, China}

The Academic Ranking of World Universities (ARWU) was first published in June 2003 by the Graduate School of Education of Shanghai Jiao Tong University, China, and is updated annually. ARWU uses six objective indicators to rank world universities including: the number of alumni and staff winning Nobel Prizes and Fields Medals; the number of highly cited researchers selected by Thomson Reuters; the number of articles published in journals of Nature and Science; the number of articles indexed in the Science Citation Index; the number of articles indexed in the Expanded and Social Sciences Citation Index; and the university's per capita performance. In excess of 1200 universities are ranked by ARWU annually and the top 500 published [24]. 
The ARWU IAB was established to provide the ARWU Team with global and academic perspectives on ARWU's current practice and future prospects. The IAB is comprised of 10 members of world renowned scholars, top policy researchers, and higher education leaders, including [25]:

- Professor Dr. Philip G. Altbach, Director, Center for International Higher Education, Boston College, USA

- Dr. Ghislaine Filliatreau, Director, Observatoire des Sciences et des Techniques, France

- Professor Dr. Charles A. Goldman, Senior Economist, RAND Corporation, USA

- Professor Dr. Pierre de Maret, Former Rector, Université Libre de Bruxelles, Belgium.

The first meeting of the ARWU IAB was held on October 30, 2011, in Shanghai, China. Additional information is accessible via link [25].

\subsection{International Advisory Committee of UNESCO}

The United Nations Educational, Scientific and Cultural organization (UNESCO) is a specialized agency of the United Nations (UN). Its purpose is to contribute to global peace and security by promoting international collaboration through education, science, and culture in order to further universal respect for justice, the rule of law, human rights, and the fundamental freedoms proclaimed in the United Nations Charter. UNESCO has 195 member states [26] and nine associate members [27].

The IAC is the body ultimately responsible for advising UNESCO on the planning and implementation of the program as a whole. It comprises 14 members serving in a personal capacity, appointed by the UNESCO Director-General, and selected for their authority in the field of the safeguarding of documentary heritage. The Director-General convenes the IAC in ordinary session every two years.

To organize its work, the IAC establishes and amends its own Rules of Procedure, which are regularly updated on its website, and maintains appropriate subsidiary bodies or subcommittees [27].

In particular, the IAC maintains an overview of the policy and strategy of the Memory of the World Program. It therefore monitors the global progress of the program, considers reports from its subcommittees, from regional committees and from the Secretariat, and in turn advises these bodies on their functions and responsibilities. As necessary, it revises and updates the General Guidelines of the Memory of the World International Register and is responsible for approving additions to, or deletions from, the register. It builds the structures of the Program with the intent of creating a sound framework for the future maturing of Memory of the World into the status of a UNESCO Recommendation and ultimately a UNESCO Convention. 
The operation of each subcommittee and regional committee is reviewed at every ordinary session of the IAC, in order to ensure that structures are kept relevant to current needs. The IAC consists of 14 members representing 14 countries. Members of the IAC (2013/2014) included [26]:

- Ms. Helena R Asamoah-Hassan, Ghana

- Ms. Alla Aslitdinova, Tajikistan

- Ms. Luciana Duranti, Italy

- Mr. Michael Heaney, United Kingdom

- Ms. Nada Moutassem Itani, Lebanon

- Mr. Hedi Jallab, Tunisia.

\subsection{International Advisory Council, APCO, Worldwide}

APCO is an independent global communication, stakeholder engagement, and business strategy firm. APCO Worldwide has more than 30 offices in major business, financial, political, and media capitals throughout the Americas, Europe, the Middle East, Africa, and Asia [28]. The organization's IAC and its three subgroups are comprised of more than 40 recognized global leaders and include: former elected politicians; leaders of business and industry; academics at leading universities; world-class journalists and editors; diplomats and policy experts [28]. Each member offers clients invaluable real-world knowledge. They are individuals who understand the complex issues faced by clients because they have encountered, and successfully exploited and overcome, similar opportunities and challenges in their own careers. Clients are able to obtain informed and valuable guidance from either individual members or from a select group of members containing varying perspectives to enable them to make the right decisions for their particular situations.

\section{How Can an IAB/IAC Be Effective and Beneficial?}

In order for an IAB/IAC to be effective and beneficial for an organization, it is crucially important to ensure that the main management team of the institution supports the concept of the board's establishment and fully comprehends its purpose and function. It is also of paramount importance for its president to encourage and establish a good working relationship among the members, and between the board and senior management. The duties of the board should be unambiguously understood by the university council or senate, and by the board members. The board should focus on broad subjects relevant to goals, policy and program issues and not on the detailed managerial and operational aspects of the organization. 
The IAB/IAC should work collaboratively with the organization's main management team, for example with the University Council. Its efforts should be directed toward the measurement and evaluation of the organization's activities aimed at meeting the objectives outlined in the organization's strategic plan, and in addressing relevant recommendations. As previously mentioned, the board does not have decision-making powers, but assists by enlightening and guiding the institutional management on strategic matters and provides an expert consultative mechanism. The management team is ultimately responsible for applying board recommendations and advice in accordance with their needs and priorities.

\section{Summary}

In this chapter, we have outlined the definition, objectives, composition, and functions of IABs and IACs in a number of institutions and organizations. The main role of IABs and IACs is to offer advice and guidance, especially on strategic matters, to assist and empower organizations' executive boards to enable their operational tasks to be successfully conducted and completed. Most boards and councils mentioned in this chapter have memberships of less than 20, and meet biannually.

IABs and IACs provide invaluable aid to concerned institutions in helping to concentrate their focus on strategic imperatives. They are also able to provide substantive and effective support in the building of international status, recognition, and reputation.

\section{Appendix}

Agenda of the sixth meeting of the IAB of KAU

King Abdulaziz University (KAU), International Advisory Board (IAB)

Sixth Meeting, 22-24 November 2013, Bilkent University, Ankara, Turkey

Theme: Towards Excellence in Teaching and Learning, Part 2

AGENDA

Day 1, Friday 22nd November 2013

\begin{tabular}{l|l}
\hline Time & Item \\
\hline $07.00-08.30$ p.m. & $\begin{array}{l}\bullet \text { KAU Strategic Plan III } \\
\bullet \text { KAU will present its Strategic Plan III (2015-2019) }\end{array}$ \\
\hline $09.00-11.00$ p.m. & $\bullet$ KAU Banquet Dinner \\
\hline
\end{tabular}


Day 2, Saturday 23rd November 2013

\begin{tabular}{|c|c|}
\hline Time & Item \\
\hline 08.30-09.30 a.m. & $\begin{array}{l}\text { - Opening Session: } \\
\text { - Welcoming Words by KAU President and Bilkent President } \\
\text { - Brief presentation on the summary of IAB-5 by Prof. Adnan Zahed } \\
\text { - Presentation on Bilkent University by Prof. Abdullah Atalar }\end{array}$ \\
\hline 09.30-11.00 a.m. & $\begin{array}{l}\text { - Group Meetings } 1 \\
\text { - Group A and Group B will meet to formulate draft programs initialized } \\
\text { during e-communications between board members }\end{array}$ \\
\hline $11.00-11.30$ a.m. & Break \\
\hline $11.30-01.00$ p.m. & $\begin{array}{l}\text { - Group Meetings } 2 \\
\text { - A continuation of Group Meetings } 1\end{array}$ \\
\hline 01.00-02.00 p.m. & Lunch \\
\hline 02.00-03.30 p.m. & $\begin{array}{l}\text { - Group A: Draft Program Presentation } \\
\text { - Group A will present its draft program } \\
\text { - The program will be discussed by all IAB members to enrich its } \\
\text { contents }\end{array}$ \\
\hline 03.30-05.00 p.m. & $\begin{array}{l}\text { - Group B: Draft Program Presentation } \\
\text { - Group B will present its draft program } \\
\text { - The program will be discussed by all IAB members to enrich its } \\
\text { contents }\end{array}$ \\
\hline 08.00-10.00 p.m. & Bilkent University Occasion \\
\hline
\end{tabular}

Day 3, Sunday 24th November 2013

\begin{tabular}{l|l}
\hline Time & Item \\
\hline $09.00-10.50$ a.m. & $\begin{array}{l}\text { ・ Group Meetings 3 } \\
\text { Group A and Group B will each meet to formulate their final pro- } \\
\text { grams, taking into account the previous day (Saturday) IAB members' } \\
\text { comments }\end{array}$ \\
\hline $10.50-11.10$ a.m. & Break \\
\hline $11.10-01.00$ p.m. & $\begin{array}{l}\bullet \text { Group Meetings 4 } \\
\text { • A continuation of Group Meetings 3 }\end{array}$ \\
\hline $01.00-02.00$ p.m. & Lunch \\
\hline $02.00-03.30$ p.m. & Group A: Final Program Presentation and Discussion \\
\hline $03.30-03.45$ p.m. & Break \\
\hline $03.45-05.15$ p.m. & Group B: Final Program Presentation and Discussion \\
\hline $05.15-05.30$ p.m. & Conclusion and Final Remarks \\
\hline
\end{tabular}

Open Access This chapter is distributed under the terms of the Creative Commons Attribution Noncommercial License, which permits any noncommercial use, distribution, and reproduction in any medium, provided the original author(s) and source are credited. 


\section{References}

1. http://www.odgersberndtson.co.uk/fileadmin/uploads/united-kingdom/Documents/K_I/ The_Role_of_Advisory_Boards_-_Who_What_Why_and_How.pdf

2. Zahed, A., Hegazy, A., \& Nahas, M. N. (2011). Establishing the International Advisory Board for King Abdulaziz University. Final Report (in Arabic), March 2011.

3. http://business.leeds.ac.uk/about-us/our-advisory-board/

4. http://www.business-school.ed.ac.uk/about/structure/advisory-board

5. Tayeb, O., \& Zahed, A. (2013). Towards a world-class university the role of international advisers. A paper presented at the 5th International Conference on World Class University, November 3-6, 2013, Shanghai, China.

6. http://iab.kau.edu.sa/Default.aspx?Site_ID $=975 \& \operatorname{lng}=\mathrm{EN}$

7. http://kau.edu.sa

8. Zahed, A., Hegazy, A., \& Nahas, M. N. (2011). Activating the International Advisory Board for King Abdulaziz University. Final Report (in Arabic), October 2011.

9. Zahed, A., Hegazy, A., \& Nahas, M. N. (2012). Performance evaluation of the International Advisory Board for King Abdulaziz University. Final Report (in Arabic), May 2012.

10. Zahed, A., Hegazy, A., \& Nahas, M. N. (2012). Preparation for the fourth meeting of the International Advisory Board for King Abdulaziz University. Final Report (in Arabic), December 2012.

11. Zahed, A., Hegazy, A., \& Nahas, M. N. Documentation of the fifth meeting of the International Advisory Board for King Abdulaziz University. Final Report (in Arabic), June 2013.

12. Zahed, A., Hegazy, A., \& Nahas, M. N. (2014). Documentation of the sixth meeting of the International Advisory Board for King Abdulaziz University. Final Report (in Arabic), January 2014.

13. http://www.kaust.edu.sa/presidents-international-advisory-council.html

14. http://www.lunduniversity.lu.se/about/about-lu/university-world-rankings

15. http://www.unibocconi.eu/wps/wcm/connect/Bocconi/SitoPubblico_EN/Navigation+Tree/ Home/About+Bocconi/Organization/International+Advisory+Council/

16. http://www.bsg.ox.ac.uk/people/international-advisory-board1.

17. http://www.srmuniv.ac.in/acdemics/international-advisory-board

18. http://provost.tamu.edu/initiatives/councils-task-forces-folder/international-advisoryboard-inclusive/international-advisory-board

19. http://www.lunduniversity.lu.se/

20. http://www.jcu.edu.au/cairnsinstitute/people/JCUTST_057670.html

21. http://www.helsinki.fi/iiaa/introduction/iab.htm

22. http://www1.kfupm.edu.sa/iab/about.html

23. http://www1.kfupm.edu.sa/iab/newsletter.html

24. http://www.shanghairanking.com/aboutarwu.html

25. http://www.shanghairanking.com/aboutiab.html

26. http://www.unesco.org/new/en/communication-and-information/flagship-project-activities/ memory-of-the-world/about-the-programme/international-advisory-committee-iac/

27. http://en.wikipedia.org/wiki/UNESCO

28. http://www.apcoworldwide.com/content/aboutapco/international_advisorycouncil.aspx

29. http://www.apcoworldwide.com/content/aboutapco/about_apco.aspx 